\title{
Short Communication: The lifecycle of Neocaridina denticulata and $N$. palmata in aquariums
}

\author{
HANAN HASSAN ALSHEIKH MAHMOUD ${ }^{1,2}$, MOH. HUSEIN SASTRANEGARA ${ }^{2}$, \\ ENDANG SRIMURNI KUSMINTARSIH ${ }^{2, \bullet}$ \\ ${ }^{1}$ Department of Fisheries Science, College of Natural Resources and Environmental Studies, University of Bahri. Khartoum, Sudan \\ ${ }^{2}$ Faculty of Biology, Universitas Jenderal Soedirman. Jl. Suparno No 63, Grendeng, Purwokerto, Banyumas 53122, Central Java, Indonesia. \\ Tel.: +62-281-638794, Fax.: +62-281-631700, `email: endangsk2402@gmail.com; endang.kusmintarsih@unsoed.ac.id
}

Manuscript received: 3 December 2019. Revision accepted: 9 April 2020.

\begin{abstract}
Mahmoud HHA, Sastranegara MH, Kusmintarsih ES. 2020. Short Communication: The lifecycle of Neocaridina denticulata and N. palmata in aquariums. Biodiversitas 21: 2396-2402. The study on the life cycle of Neocaridina spp. is important because it plays a major role in the economy and trade between countries. However, there is a lack of sufficient studies on this particular topic. One of the factors that influence Neocaridina spp. life production is its life cycle and the associated water parameters. The objectives of this study were to conduct, observe, and record the life cycle of Neocaridina denticulata and N. palmata and the associated with water parameters (temperature, $\mathrm{pH}$, ammonia, nitrite, and oxygen) in the aquarium. The results showed that there was no difference in the life cycle stages between the two shrimp species. Both species reached the first sexual maturity stage of the life cycle at 75 days, with the maximum body length of the mature shrimp ranging from $2.30-3.00 \mathrm{~cm}$. The eggs became larvae in 15 days, larvae reached the juvenile stage after 60 days, and the juvenile became mature in 15 days. The number of eggs was influenced by the body size of the female shrimps; smaller females produced fewer eggs. Optimal water quality varies by species and must be monitored to ensure growth and survival. The temperature range in this study was $25-28^{\circ} \mathrm{C}$ and the $\mathrm{pH}$ was $6.5-8.0$. The ammonia level was in the range between 1.21 and $1.72 \mathrm{mg} / \mathrm{L}$, the nitrate was between 0.06 and $7.91 \mathrm{mg} / \mathrm{L}$, and the oxygen was around 5.5-7.9 mg/L. All of the water quality parameters in this study are within the acceptable range for Neocardina cultivation.
\end{abstract}

Keywords: Aquarium, life cycle, Neocaridina denticulata, Neocaridina palmata, ornamental shrimp

\section{INTRODUCTION}

Two freshwater ornamental shrimp species have been currently developed; namely, Neocaridina denticulata and Neocaridina palmata. These shrimps are indigenous species of Japan, Korea, China, Taiwan, and Indonesia (Hung et al. 1993). According to Cai (1996), N. denticulata and $N$. palmata species originate from ponds, rivers, agricultural canals, mountain streams, and reservoirs.

Genus Neocaridina is classified under the phylum Arthropoda, Subphylum Crustacea, class Malacostraca, order Decapoda, infraorders Caridea which is dominated by the family Atyidae (Ariyanathan and Sesh Serebiah 2016; Lai and Shy 2009). Neocaridina sp has been growing in industry popularity over the past years (Lai and Shy 2009; Tropea et al. 2015). N. denticulata is distinguished by its red, yellow, and blue color, while $N$. palmata is characterized by a transparent color that gives a great presentation when in contrast to green aquatic plant or against a dark-colored background. Many people rear these shrimps as ornamental in aquariums because of the colorful presentation of the shrimps (Heerbrandt and Lin 2006; Ganesh 2015; Pantaleão et al. 2015).

The characteristics of Neocaridina include; maturity size of $2-3 \mathrm{~cm}$ in total length, high resistance to environmental conditions, fluctuation in the quality of breeding, and a high survival rate. Shrimps have a high tolerance to a wide range of water quality parameters in the aquarium such as $\mathrm{pH}$ ranged between 6.5-8.04, temperature between $24-29^{\circ} \mathrm{C}$, oxygen between $5-7 \mathrm{mg} / \mathrm{L}$, ammonia ranged from $0.1-1.9 \mathrm{mg} / \mathrm{L}$, and nitrate ranged from $0.1-10.0$ mg/L (Ganesh 2015; Ariyanathan and Sesh Serebiah 2016; Heerbrandt and Lin 2006.). This tolerance provides the opportunity for Neocaridina sp to develop and improve its breeding performances. However, there is information gap in current research of Neocaridina species regarding the species' characteristics, therefore further observations are required to improve the performance of the Neocaridina species.

One of the factors that influence the success of Neocaridina shrimp production is its life cycle i.e. egg, larvae, juvenile, and adult (Hung et al. 1993; Shih and Cai 2007). Neocaridina an adult produces relatively smallsized eggs which range from $1-1.19 \mathrm{~mm}$ with a long planktonic phase (Shokita 1981; Lai and Shy 2009). The common type of development ranges between 9 and 12 planktonic larval stages and the pleopods of the larval stage is not yet developed (Lai and Shy 2009), the pleopods develop in the juvenile stage.

As of recent years, the trading of freshwater ornamental shrimp species has become a highly profitable and the fastest growing industry in the world. Currently, pressure on wild populations is building up, creating a wide array of environmental implications. Breeding in the aquarium is minimizing the negative impacts on the natural environment and is providing sustainable supply to the 
market. The scope of shrimp being reared in a planted aquarium or dedicated aquaria is increasing among the hobbyist (Tropea and Lopez-Greco 2015; Ganesh 2015). The successful life cycle and mass production of this shrimp can provide an avenue for the aquarium industry and contribute to national income. Therefore Neocaridina sp has potential to improve the economy and trade between countries and concerted effort is required to provide the information gap on these species and their biological nature and how they reproduce. There are few studies that focused on the life cycle of $N$. denticulata whilst $N$. palmata does not have any published information about its life cycle. The current research is the first to conduct studies on these two types of shrimp in Indonesia.

The aim this research is to observe and record the life cycle of $N$. denticulata and $N$. palmata and the maximum length reached per adult female; every stage of a life cycle in the two species under laboratory conditions and the water parameters such as water temperature, $\mathrm{pH}$, ammonia, nitrate, and oxygen in aquarium.

\section{MATERIALS AND METHODS}

\section{Sampling collection sites}

Samples of Neocaridina species were collected from Purbalingga fish market which is located in Central Java, Indonesia showed in Figure 1. Purbalingga fish market (Pasar Ikan Purbalingga) is one of the main suppliers of ornamental shrimp aquarium in Central Java.

\section{Study Species of $N$. denticulata and $N$. palmata}

The study was conducted on two species of freshwater ornamental shrimp from the family Atydiae: $N$. denticulata and N. palmata. A total of 60 samples, 30 samples from $N$. denticulata, and 30 samples from $N$. palmata were kept an aquarium in order to know their life cycle. 30 samples of each species 15 male and 15 female breeding in the aquarium from $14^{\text {th }}$ June 2019 to $10^{\text {th }}$ August 2019. N. denticulata which shown in Figure 2.A-B) and N. palmata showed in Figure 2.C).

\section{Aquarium preparation and maintenance}

The same sizes of glass aquarium $(50 \mathrm{~cm}$ length, $40 \mathrm{~cm}$ width, and $40 \mathrm{~cm}$ height) were used for conditioning females and males of $N$. denticulata and N. palmata. 30 samples from each species, 15 males and 15 females, were kept in two aquariums filled with $30 \mathrm{~L}$ underground water. Powerhead filters were used with the white stone substrate. Aerated tap water was used as the source of oxygen. Aeration pump was provided throughout the study period. Dissolved oxygen, nitrate, and ammonia concentrations were measured weekly until nine weeks while $\mathrm{pH}$ and temperature were measured daily until eighty days, during the study period, by the $\mathrm{pH} /$ conductivity meter ( $\mathrm{pH} /$ Cond.Meter Jenway, China). These are the main deciding factors in establishing optimal parameters for the aquarium breeding (Ariyanathan and Sesh Serebiah 2016), and Java moss, Vesicularia dubyana was used for shelter in the aquariums. The water in the aquarium was renewed partially every three weeks to remove feces and food remains. Adult shrimp and their larvae were fed by pellets (containing $40 \%$ crude protein) twice a day (08:00 and 17:00). The length of the adult, larvae, and egg were measured under stereomicroscope using a ruler and Millimeter block. The eggs were calculated from each female carrying eggs using the needle and microscope. Simple statistical Descriptive analysis (SPSS version 16.0) was performed to analyze the data.
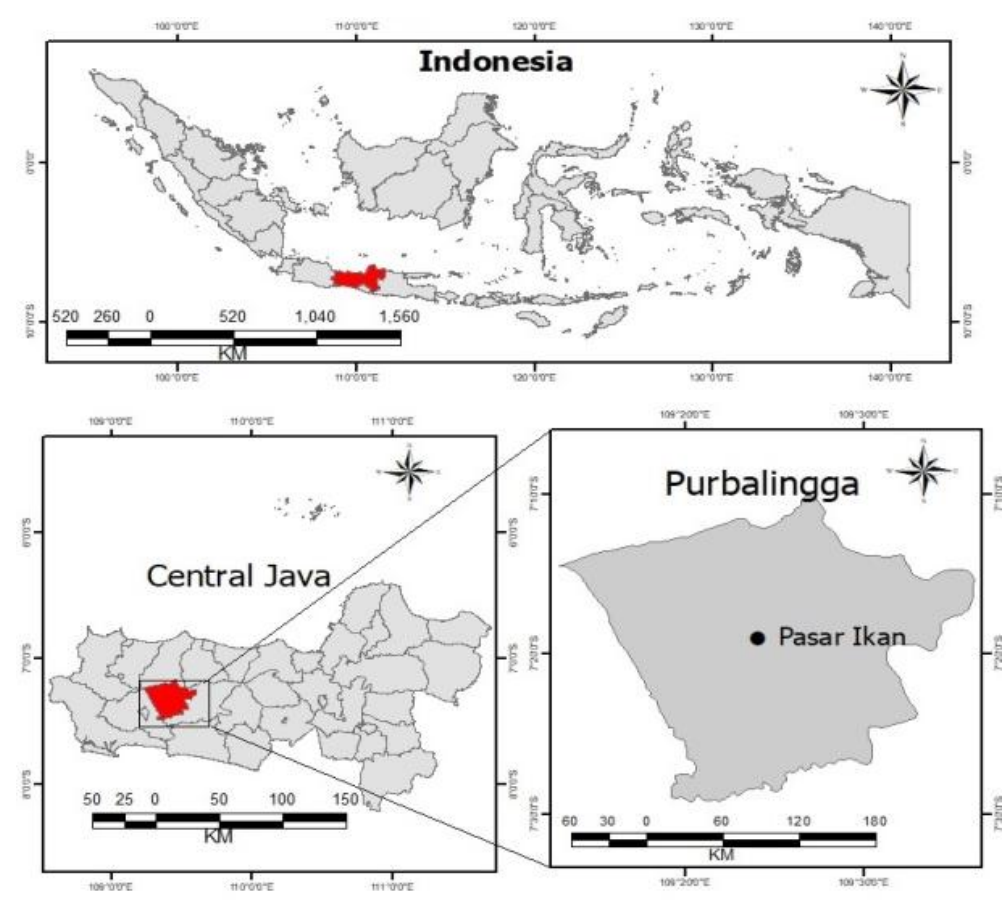

Figure 1. Location map of the study area showing fish market (Pasar Ikan) in Purbalingga, Central Java, Indonesia 


\section{Life cycle of $N$. denticulata and $N$. palmata}

Matured males and females of $N$. denticulata and $N$. palmata were bought from the Purbalingga fish market, only females with saddle and healthy males were used. The observation was carried out until female shrimp become ovigerous. Fifteen of ovigerous females from each species were moved to the individual aquarium. The number of eggs produced by each female was counted by using a hand lens and recorded. Females were removed after the larvae hatched separately, and the number of larvae that hatched from each female was counted. All larvae hatched were used in the next experiment. Healthy larvae were reared in the aquarium, observe, and measured the length of each stage was carried out until all larvae reached to maturity stage (Yang and Ko 2003).

\section{RESULTS AND DISCUSSION}

Thirty female samples divided into $15 \mathrm{~N}$. denticulata and $15 \mathrm{~N}$. palmata were kept in a glass aquarium for the purpose of studying their lifecycle. The two species reached the first maturity stage at around 75 days old, because they belong to the same genus of Neocaridina. This result was similar to Ganesh (2015) who reported that Caridina cf. babaulti was found to be able to reach the first maturity around 75 days old.

After the female has reached the stage of maturity, the presence of visible mark with a dark color located on top of shrimp between the head and abdomen can be seen through the cephalothorax region of the females of $N$. denticulata and $N$. palmata which measured about $2.0 \mathrm{~mm}$ in length, this signal was found in the two species shown in Figure 2.D. While for males, maturity appears on appendix, masculina on the second pleopod shown in Figure 2.E. In adult male appendix masculina appeared large in size, inner branch of the second pleopod in male serve in spermatophores transfer and the distal of end-organ covered with an increasing number of setae. A similar observation was reported by Englund and Cai (1999) who stated that morphological differences between males and females were only observed when $N$. sinensis reached maturity with the appearances of endopod and appendix masculina in males.

Fifteen pairs of matured males and females of $N$. denticulata and $N$. palmata each were placed in two breeding aquariums. The mating process for both species took place three days after the introduction of males and females into the same aquarium. Females of the two species were molted prior to mating. This result is similar to those reported by Demas (2007) who examined females molted prior to mating, possibly to release certain chemical substances into the surrounding water before or during molting to attract potential mates. The release of this substance allows the male to detect a gravid female in the water aquarium; this signals a male that the female is ready to spawn. The result showed that both molting and mating occurred rapidly in less than $10 \mathrm{sec}$. During the mating process, males and females faced each other, and sperms were deposited into the genital opening of females using its appendix masculina. This result was similar to that observed by Nur and Christianus (2013) who reported that sperms in cherry shrimp were deposited into the genital opening of females using its appendix masculina while the molting happened in the time of mating. The eggs were fertilized when they passed through the sperm into the brood pouch. The pouch was formed by pleopods and overhanging of the pleura of the female. This result was in agreement with Adiyodi and Adiyodi (1994) who reported that eggs were incubated in the brood pouch until hatch. A day after mating, the female was observed to carry fertilized eggs shown in Figure 2.F-G.

Fertilized eggs were oval in shape and the color varied from greenish to yellowish. The egg size was comparatively large. The length of eggs ranged from 1.0 $\mathrm{mm}$ to $1.19 \mathrm{~mm}$ (Figure 3.A) and $0.5 \mathrm{~mm}$ in width (Figure 3.B). There was no difference in the size and width of eggs in the $N$. denticulata and $N$. palmate. This result agreed closely with Ketse (2006) who reported that fertilized eggs in cherry shrimp carry green or yellow eggs with an average length of $1.19 \mathrm{~mm}$. Thin ribbon-like filament binds the eggs in grape-like pouch and attached it to the female's pleopod was shown in Figure 3.C-D.

The number of the eggs depends on the size of females in the two species $N$. denticulata and $N$. palmata, smaller females produced fewer eggs compared to the larger females and the number of eggs produced by each female ranged between 21 and 60 eggs for $N$. denticulata as shown in Table 1 and from 21-58 eggs for $N$. palmata shown in Table 2. The study indicated that number of eggs in each female of both the $N$. denticulata and $N$. palmata differed according to the length of the shrimp. This phenomenon is attributed to the size of the shrimp. The small-sized shrimps accommodated a small ovary yet produced relatively large eggs; as a result, the number of eggs produced by the small-sized shrimps was relatively small. The present results were similar to previous results reported by Schram (1986) who showed that females with small length produce 21 eggs while the large length produced more than 40 eggs per female. The relationship between length and number of eggs produced by females of $N$. denticulata and N. palmata is shown in Figure 4.A-B.

After the eggs hatched become larvae, only healthy larvae were used for the next experiment. The newly hatched larvae of the two species looked similar to the miniature version of the adult with the length $3.3 \mathrm{~mm}$ in 24 hours after the eggs hatch. The length of larvae was similar to N. denticulata and N. palmata is shown in Figure 3.E-F.

The juvenile for both species took 15 days to reach the first maturity stage. The $N$. denticulate and $N$. palmata life cycle starts from the egg, larvae, juvenile, and adult. The results showed no difference in the life cycle of the two species found shown in Table 3.

Water parameters are the most important factors affecting the survival and growth of ornamental shrimp and during maintenance, the period is observed for water qualities. The water parameter that was checked during the study period was the range of dissolved oxygen between $5.5 \pm 7.9 \mathrm{mg} / \mathrm{L}$. In this study, the oxygen was still in the category of good for sustaining life in the aquarium. The 
oxygen is used in the combustion of fuel (food) to generate activity, such as swimming activity, growth, and reproductive. While the range of values for ammonia ranged between $1.21 \pm 1.72 \mathrm{mg} / \mathrm{L}$ and nitrate between $0.06 \pm 7.91 \mathrm{mg} / \mathrm{L}$, these water parameters are still under normal conditions, implying that they are not harmful to shrimp, and do not affect survival rate and growth performance of the shrimp. The results matched with Ganesh (2015) who reported that Caridina cf babaulti shrimp breeding in the aquarium with ammonia $1.6 \mathrm{mg} / \mathrm{L}$ and nitrate $<0.1 \mathrm{mg} / \mathrm{L}$. Ammonia is a nitrogen gas excreted from the shrimp by the reshuffle protein metabolism, either in the form of shrimp own excrement (feces and urine) as well as from the rest of the feed (Demas 2007). The oxygen, ammonia, and nitrate range were measured weekly during the study period shown in Table 4.

Table 1. Number of eggs produced by each female of $N$. denticulate

\begin{tabular}{llll}
\hline Variable name & $\begin{array}{c}\text { Number of } \\
\text { samples }\end{array}$ & Means & $\begin{array}{c}\text { Std. } \\
\text { Deviation }\end{array}$ \\
\hline Length/ cm & 15 & $2.0 \pm 3.0$ & .18770 \\
Number of eggs & 15 & $21 \pm 60$ & 10.32685 \\
\hline
\end{tabular}

Table 2. Number of eggs produced by each female of $N$. palmata
Table 3. Stages of the life cycle of the two species studied during the study period

\begin{tabular}{|c|c|c|}
\hline $\begin{array}{l}\text { Life cycle stage } \\
\text { of } N \text {. denticulata } \\
\text { and } N \text {. palmata }\end{array}$ & Length & Period /day \\
\hline Egg & $1.0-1.19 \mathrm{~mm}$ & 15 days to become larva \\
\hline First larvae & $2.0-3.3 \mathrm{~mm}$ & 24 hour the length $3.3 \mathrm{~mm}$ \\
\hline Second larvae & $4.5-5 \mathrm{~mm}$ & 14 days \\
\hline Third larvae & $8-9 \mathrm{~mm}$ & 30 days \\
\hline Fourth larvae & 9-1 Cm & 45 days \\
\hline Juvenile & $1.2-1.5 \mathrm{~cm}$ & 15 days to become adult \\
\hline Adult & $2.3-3.0 \mathrm{~cm}$ & $\begin{array}{l}2-3 \text { days to become } \\
\text { ovigerous }\end{array}$ \\
\hline
\end{tabular}

Table 4. Ranges of water parameters measured weekly during the study period

\begin{tabular}{llcc}
\hline \multicolumn{1}{c}{ Variable } & $\begin{array}{c}\text { Number of } \\
\text { weeks }\end{array}$ & Means & $\begin{array}{c}\text { Std. } \\
\text { Deviation }\end{array}$ \\
\hline Oxygen/mg/L & 9 & $5.50 \pm 7.90$ & 0.90021 \\
Nitrate/ mg/L & 9 & $0.06 \pm 7.91$ & 3.07276 \\
Ammonia/ mg/L & 9 & $1.21 \pm 1.72$ & 0.16109 \\
\hline
\end{tabular}

Table 5. Ranges of Water Parameters Measured Daily during the Study Period

\begin{tabular}{llll}
\hline \multicolumn{1}{c}{ Variable } & $\begin{array}{c}\text { Number of } \\
\text { days }\end{array}$ & \multicolumn{1}{c}{ Means } & \multicolumn{1}{c}{$\begin{array}{c}\text { Std. } \\
\text { Deviation }\end{array}$} \\
\hline Temperature $/{ }^{\circ} \mathrm{C}$ & 80 & $25.00 \pm 28.00$ & .89443 \\
$\mathrm{pH}$ & 80 & $6.50 \pm 8.00$ & .54558 \\
\hline
\end{tabular}

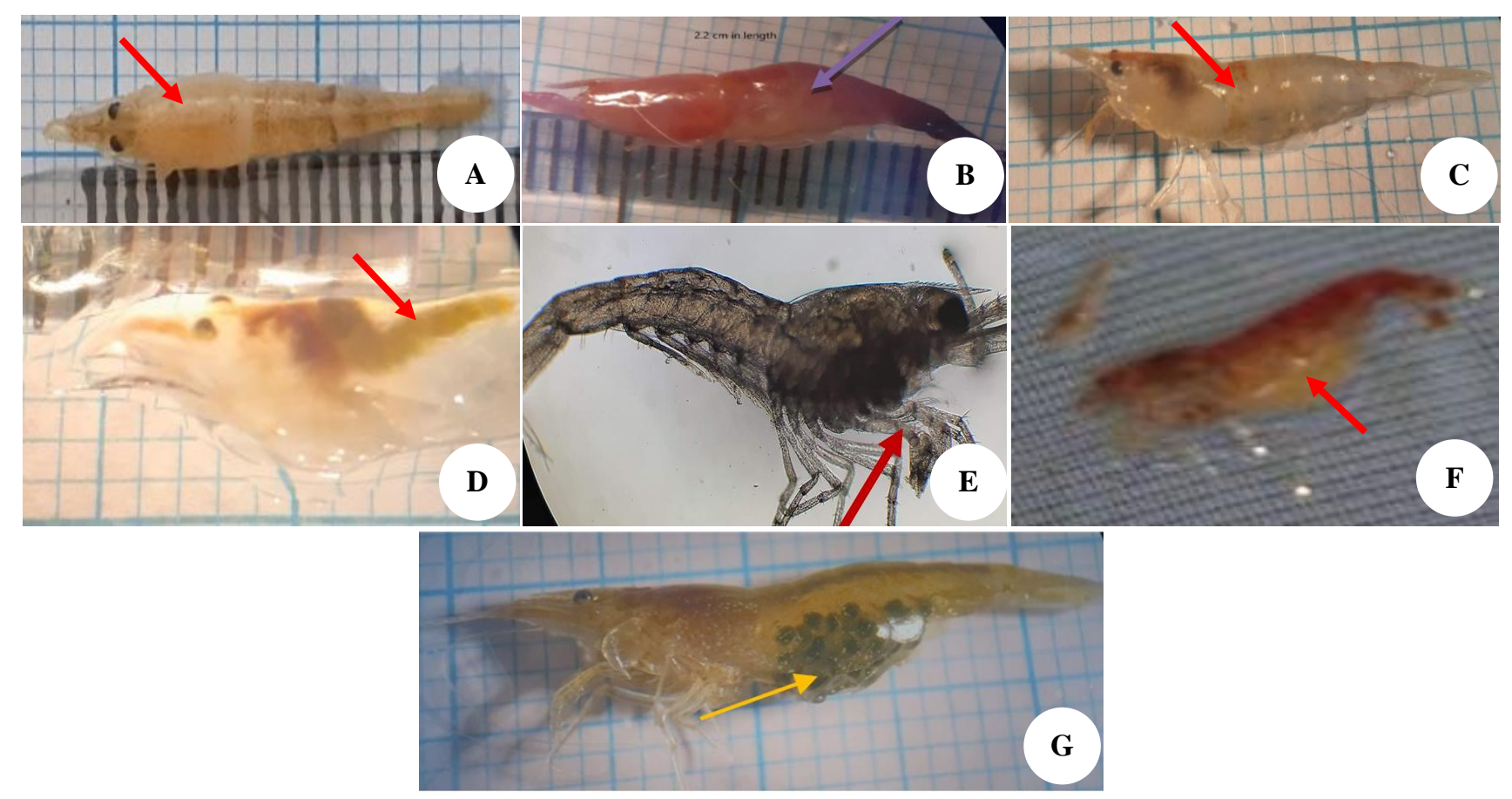

Figure 2. A. Red arrow indicates the yellow-colored $N$. denticulate, B. Purple arrow indicates the red colored N. denticulata, C. Arrow indicates the transparent colored $N$. palmata, D. Visible mark in mature female cephalothorax (red arrow), E. Appendix masculina on the second pleopod of the matured male (red arrow), F. N. denticulata carrying fertilized eggs (red arrow), G. N. palmata carrying fertilized eggs (yellow arrow) 


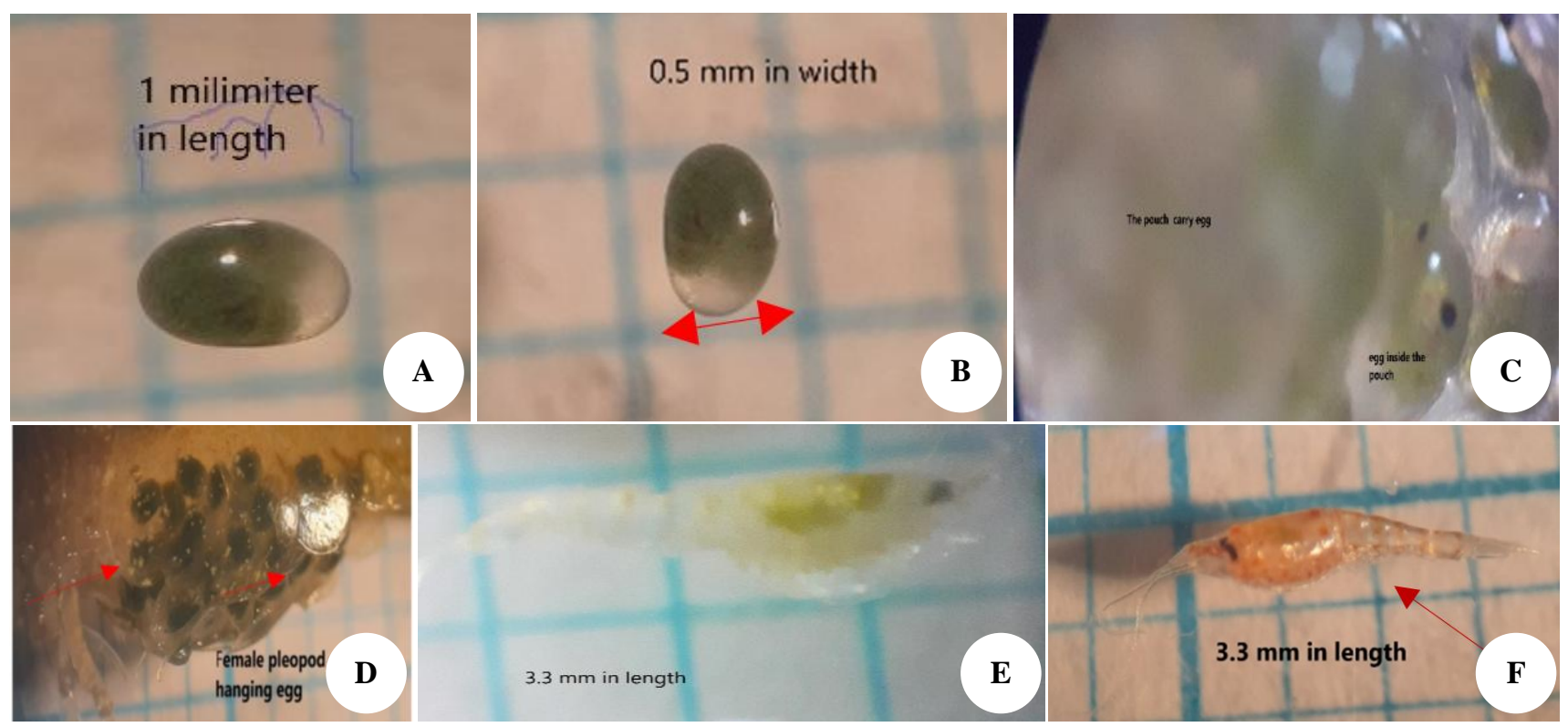

Figure 3.A. Length of the egg (black arrow) of the two species, B. The width of the egg (red arrow). Note: one square represents one millimeter, C. The eggs in grape-like pouches, D. The egg hanging on the female's pleopod (red arrow), E. New larvae at 24 hours after hatching of $N$. palmata (red arrow), F. New larvae at 24 hours after hatching of $N$. denticulata (red arrow) under Stereo microscope
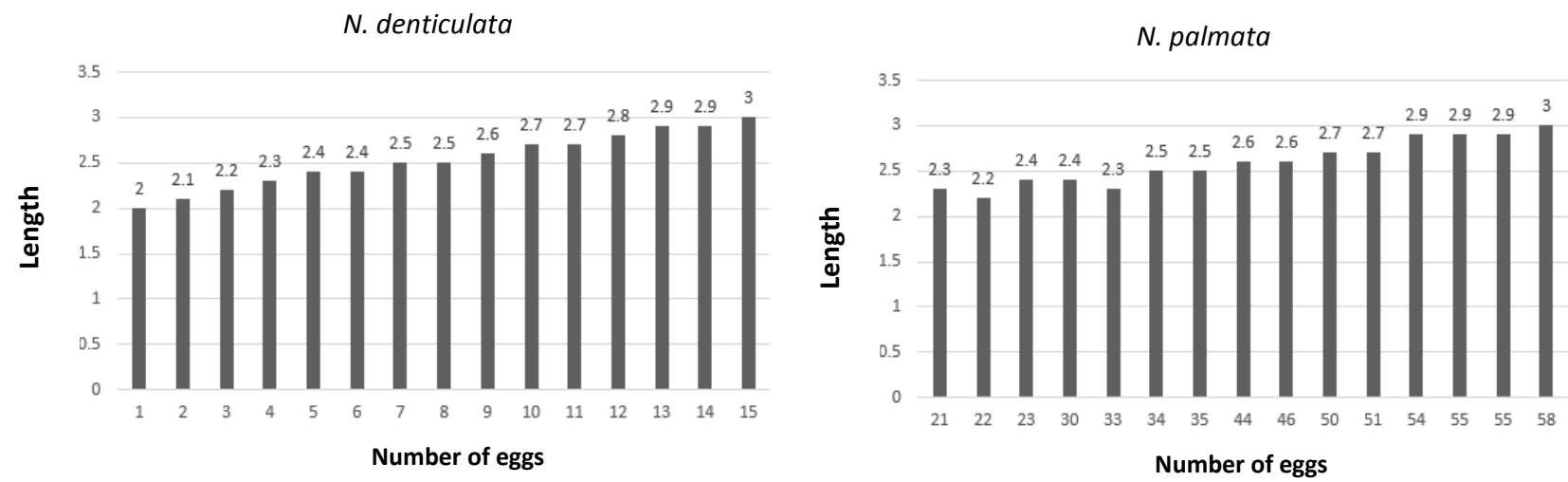

Figure 4. The number of eggs per female compared to the length of $N$. denticulata (left), and N. palmata (right)

N. denticulata

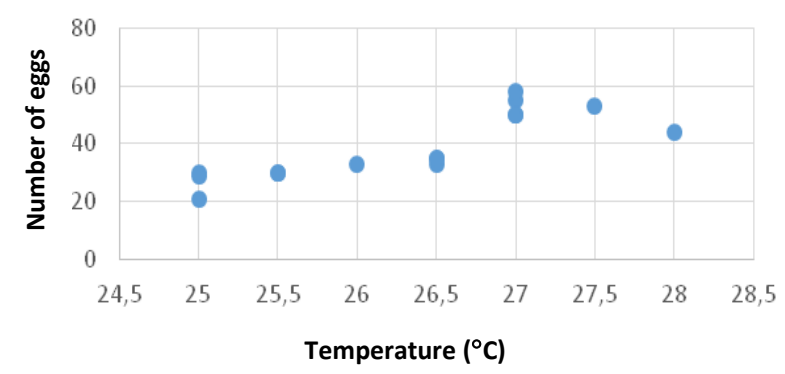

Figure 19. 5.A. The relationship between the temperature and the number of eggs per female of $N$. denticulata in the optimum temperature to produce the eggs of $27^{\circ} \mathrm{C}$

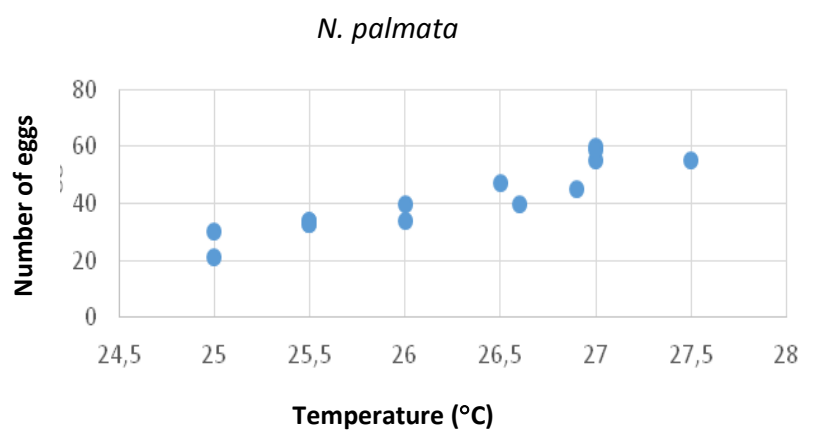

Figure 20. 5.B. The relationship between the temperature and the number of eggs per female of $N$. palmata in the optimum temperature to produce the eggs of $27^{\circ} \mathrm{C}$ 


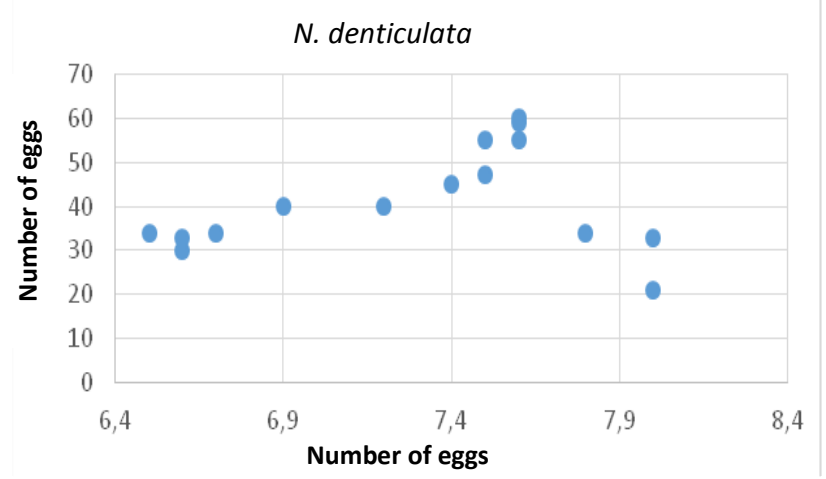

Figure 21. 6.A. The relationship between $\mathrm{pH}$ and the number of eggs produced per female of $N$. denticulata in $\mathrm{pH}$ range between $6.5-8.0 \mathrm{mg} / \mathrm{L}$ (the fluctuation depends on the change of water in the aquarium)

During the study period, ammonia, oxygen, and nitrate were checked once a week while the temperature and $\mathrm{pH}$ were checked daily in the aquarium. The present results showed that $N$. denticulata and $N$. palmata the tolerance range of water temperatures were $25 \pm 28^{\circ} \mathrm{C}$, as evidenced by its high survival and good growth performance over a 75 days period. The water temperature is very important for the life of aquatic animals because it affects growth, metabolism, and the solubility of gases in water such as oxygen and carbon dioxide. The optimum temperature of the high number of eggs from two species is $27^{\circ} \mathrm{C}$ this result was still in the range from Tropea et al. (2015) reported that water temperature ranged from $25-32^{\circ} \mathrm{C}$ and the optimum temperature was $28^{\circ} \mathrm{C}$. The $\mathrm{pH}$ ranged between $6.5 \pm 8.0$ in a range of activities that were within the range of $N$. denticulata and $N$. palmata shrimp were still able to grow and thrive. The $\mathrm{pH}$ scale is closely related to the activity of the skin (molting) for growth and reproduction similar to that observed by Ganesh (2015) breeding the cherry shrimp in $\mathrm{pH}$ ranged between 6.5-7.5. With carefully monitored water quality parameters, the two species were bred and growing well after hatching. The range of temperature and $\mathrm{pH}$ measured daily are shown in Table 5. The relationship between the numbers of eggs produced by the female of the two species and the temperature are shown in Figure 5.A.B. The relationship between the numbers of eggs produced by the female of the two species and $\mathrm{pH}$ in the aquarium is shown in Figure 6.A-B

In conclusion, Neocaridina denticula and N. palmata can successfully breed in laboratory conditions. There was no difference between the life cycle stages of the two shrimp species, and they both reached the first sexual maturity stage of the life cycle at 75 days, with the maximum body length of the mature shrimp ranging from $2.30-3.00 \mathrm{~cm}$. The eggs became larvae in 15 days, larvae reached the juvenile stage after 60 days, and the juvenile became mature in 15 days. The number of eggs was influenced by the body size of the female shrimp of the two
N. palmata

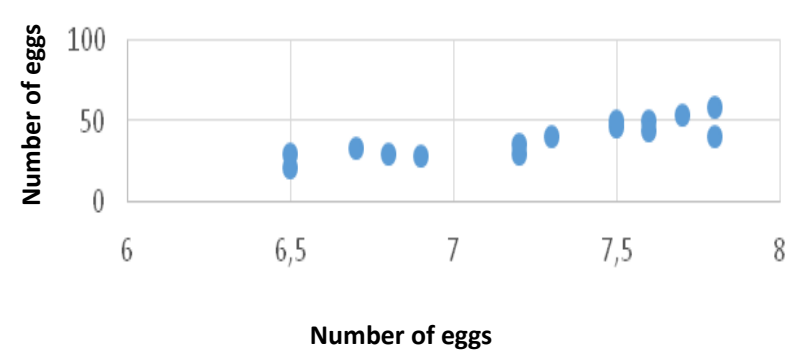

Figure 22. 6.B. The relationship between $\mathrm{pH}$ and the number of eggs produced per female of $N$. palmata in $\mathrm{pH}$ range between 6.5$7.8 \mathrm{mg} / \mathrm{L}$ (the fluctuation depends on the change of water in the aquarium)

species; smaller females produced fewer eggs compared to larger females. Findings of this study can be used as a guideline for culturists interested in the production of this Neocaridina species shrimp for the aquarium industry.

\section{ACKNOWLEDGEMENTS}

We are grateful to the person who provided samples of shrimps. This study was funded by a Riset Institusi University of Jenderal Soedirman, Purwokerto, Indonesia No.161/UN23/14/PN.01.00/2019

\section{REFERENCES}

Adiyodi KG, Adiyodi RG. 1994. Reproductive biology of invertebrates, Volume 6, Part B, Asexual propagation and reproductive strategies. John Wiley Sons, Chichester.

Ariyanathan G, Sesh Serebiah J. 2016. Selective and interbreeding of freshwater ornamental shrimps with endemic aquarium plants. Int $\mathbf{J}$ Curr Res Biosci Plantbiol 3 (7): 144-150. DOI: 10.20546/ijcrbp.2016.307.020.

Cai Y. 1996. A revision of the genus Neocaridina (Crustacea: Decapoda: Atyidae). Acta Zootaxon Sin 21: 129-160.

Demas P. 2007. Red Cherry Shrimp. Trop. Fish Hobbyist 56: 90-92.

Englund RA, Cai Y. 1999. The occurrence and description of Neocaridina denticulata sinensis (Kemp, 1918) (Crustacea: Decapoda: Atyidae), a new introduction to the Hawaiian Islands. Bishop Mus Occa Pap 58: 58-65.

Ganesh. 2015. Breeding and life cycle of freshwater ornamental shrimpStripe Shrimp, Caridina cf. babaulti. Int J Curr Microbiol App Sci 4 (7): 794-801.

Heerbrandt TC, Lin J. 2006. Larviculture of red front shrimp, Caridina gracilirostris (Atyidae, Decapoda). J World Aquac Soc 37: 186-190. DOI: 10.1111/j.1749-7345.2006. 0025.x

Hung MS, Chan TY, Yu HP. 1993. Atyid shrimps (Decapoda: Caridea) of Taiwan, with descriptions of three new species. J Crustacean Biol 13: 481-503.

Ketse N. 2006. The effects of selected reference toxicants on embryonic development of the freshwater shrimp Caridina nilotica (Decapoda: Atyidae). [M.Sc. Thesis], Institute for Water Research, Rhodes University, Grahamstown.

Lai HT, Shy JY. 2009. The larval development of Caridina pseudodenticulata (Crustacea: Decapoda: Atyidae) reared in the 
laboratory, with a discussion of larval metamorphosis types. Raffles Bull Zool 20: 97- 107.

Nur FAH, Christianus A. 2013. Breeding and life cycle of Neocaridina denticulata sinensis (Kemp, 1918). Asian J Anim Vet Adv 8 (1): 108115.

Pantaleão JAF, Barros-Alves SDP, Tropea C, Alves DF, NegreirosFransozo ML, López-Greco LS. 2015. Nutritional vulnerability in early stages of the freshwater ornamental "Red Cherry Shrimp" Neocaridina davidi (Caridea: Atyidae). J Crustacean Biol 35 (5): 676681.

Schra FR. 1986. Crustacea. Oxford University Press, Oxford.

Shih HT, Cai Y. 2007. Two new species of the land-locked freshwater shrimps genus, Neocaridina Kubo, 1938 (Decapoda: Caridea: Atyidae), from Taiwan, with notes on speciation on the island. Zool Stud 46 (6): 680-686.
Shokita S. 1981. Life-history of the family Atyidae (Decapoda, Caridea). Aquat Biol 12: 15-23.

Tropea C, López-Greco LS. 2015. Female growth and offspring quality over successive spawnings in a caridean shrimp Neocaridina davidi (Decapoda, Atyidae) with direct development. Biol Bull 229: 243254.

Tropea C, Stumpf L, López Greco LS. 2015. Effect of temperature on biochemical composition, growth and reproduction of the ornamental red cherry shrimp Neocaridina heteropoda heteropoda (Decapoda, Caridea). PLoS ONE 10: 119-468. DOI: 10.1371/ j.pone.0119468

Yang HJ, Ko HS. 2003. Larval development of Neocaridina denticulate sinensis (Decapoda: Caridea: Atyidae) reared in the laboratory. Korean J Syst Zool 19: 49-54. 